\title{
Tax Compliance Option during the Pandemic: Moral, Sanction, and Tax Relaxation (Case Study of Indonesian MSMEs Taxpayers)
}

\author{
Nik Amah ${ }^{1+}$, Ni Wayan Rustiarini ${ }^{2}$, and A. A. Hatmawan ${ }^{1}$ \\ ${ }^{1}$ Universitas PGRI Madiun, Indonesia \\ ${ }^{2}$ Universitas Mahasaraswati Denpasar, Indonesia
}

\begin{abstract}
This study aims at empirically analyzing the effect of tax moral, sanction, and tax relaxation on taxpayer compliance. This study result is expected to provide an option to increase taxcompliance du ring the Covid-19 pandemic. The type of this study is a quantitative study. It collects the data using a questionnaire in the form of Google form. The sampling technique of this study uses purposive sampling. The number of samples is 95 MSMEs members registered at the Department of Cooperative and Micro Enterprise, Magetan Regency, Indonesia. The data were analyzed by the multiple linear regression analy sis techniques. The analysis result shows that during the Covid-19 pandemic, taxmoralfunction was neglected in increasing tax compliance. The focus of MSMEs owners is trying tomaintain their business to survive while their tax obligations are the next priority. The considerations as their basis to carry out their tax obligation are sanction and tax relaxation. The sanction plays a strong role in increasing tax compliance which means the tax compliance ofMSMEs owners is in compliance due to coercion. Tax relaxation is another option as a solution to increase the taxpayer's compliance with MSMEs owners during the pandemic. It gives ease and relieffor MSMEs owners to fulfill their tax obligations.
\end{abstract}

Keywords: MSMEs, Sanction, Tax Moral, Tax Relaxation, Tax Compliance

JEL Codes: H26, E26, O17

\section{Introduction}

Micro, Small, and Medium Enterprises (MSMEs) play a very important role in a country's economy. In the social aspect, MSMEs are the medium to overcome poverty, reduce unemployment numbers and even reduce the crime rates. In the economic aspect, MSMEs play a role in improving society's economic level by providing employment opportunities. They are also potential in their contribution to the state budget by the tax they pay. The growth and contribution of MSMEs on employment and Gross Domestic Product (GDP) are reflected as follows:

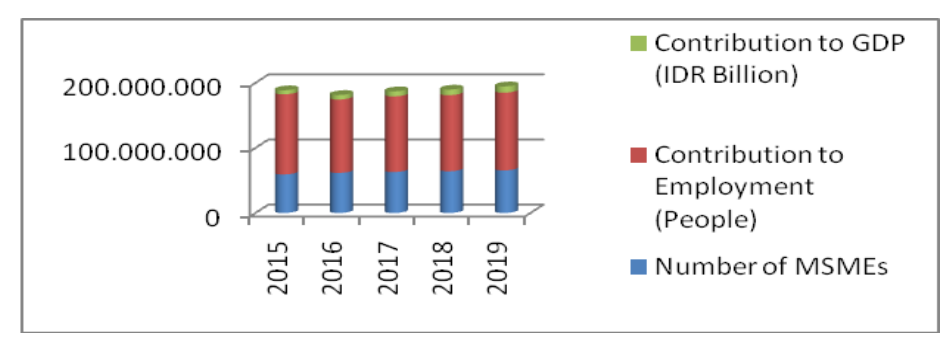

Fig. 1: Growth of the number of MSMEs and their contribution in Indonesia.

(Source: Da ta processed by authors)

+ Corresponding author. Tel.: + 62 85736831916; fax: + 62351 459400, address: Auri, No. 14-16, Madiun, Indonesia E-mail address: $\underline{\text { nikamah@unipma.ac.id }}$ 
This trend illustrates the number of MSMEs in Indonesia is increasing each year. The growth of MSMEs is also in line with their role in absorbing employment and their contribution to GDP in Indonesia. Figure 1 is also supported by the data in Table 1:

Table 1: Contribution of MSMEs to Employment and GDP

\begin{tabular}{|c|c|c|c|c|c|c|c|}
\hline Year & $\begin{array}{c}\text { Number of } \\
\text { MSMEs }\end{array}$ & $\begin{array}{c}\text { MSMEs } \\
\text { contribution } \\
\text { to } \\
\text { Employment } \\
\text { (people) }\end{array}$ & $\begin{array}{c}\text { Total } \\
\text { Employment }\end{array}$ & $(\%)$ & $\begin{array}{c}\text { MSMEs } \\
\text { contribution to } \\
\text { GDP (IDR } \\
\text { Billion) }\end{array}$ & $\begin{array}{c}\text { Total GDP } \\
\text { (IDR Billion) }\end{array}$ & $(\%)$ \\
\hline 2015 & 59.262 .772 & 123.229 .387 & 127.423 .438 & 96,71 & 6.228 .285 & 10.141 .340 & 61,41 \\
\hline 2016 & 61.651 .177 & 112.828 .610 & 116.273 .356 & 97,04 & 7.009 .283 & 11.712 .450 & 59,84 \\
\hline 2017 & 62.922 .617 & 116.431 .224 & 120.260 .177 & 96,82 & $7.820 .282,60$ & 12.840 .859 & 60,90 \\
\hline 2018 & 64.194 .057 & 116.978 .631 & 120.598 .138 & 97,00 & $8.573 .895,30$ & $14.038 .598,50$ & 61,07 \\
\hline 2019 & 65.465 .497 & 119.562 .843 & 123.368 .672 & 96,92 & $9.580 .762,70$ & $15.832 .535,40$ & 60,51 \\
\hline
\end{tabular}

(Source: The Minister of Cooperative and Small and Medium Enterprises)

Table 1 explains that the growth of the number of MSMEs has increased from year to year. The contribution of MSMEs in absorbing employment from 2015 to 2019 is in the range of 96,71\% -97,04\%. The contribution of MSMEs to GDP from 2015 to 2019 is in the range of 59,84\% - 61,41\%. However, since the Covid-19 pandemic, MSMEs and various other large-scale business fields are facing a slump. The Covid-19 has a huge impact on various life and business aspects, including MSMEs around the globe. Various policies have been issued by each country to help MSMEs to survive during the pandemic. Malaysia, Singapore, Thailand, Vietnam are some examples.

Table 2: Policy Responses of some ASEAN Countries in facing the Covid-19

\begin{tabular}{|c|c|c|c|c|c|c|c|c|}
\hline \multirow[b]{2}{*}{ Country } & \multirow{2}{*}{$\begin{array}{c}\text { Labor } \\
\text { Wage } \\
\text { Subsidy }\end{array}$} & \multicolumn{2}{|c|}{ Suspension } & \multicolumn{2}{|c|}{$\begin{array}{l}\text { Financial } \\
\text { Instrument }\end{array}$} & \multicolumn{3}{|c|}{ Structural Policy } \\
\hline & & $\begin{array}{c}\text { Income/ } \\
\text { Cooperate } \\
\text { Tax }\end{array}$ & $\begin{array}{c}\text { Value } \\
\text { Added } \\
\text { Tax }\end{array}$ & $\begin{array}{l}\text { Direct } \\
\text { Loan to } \\
\text { MSMEs }\end{array}$ & Subsidy & $\begin{array}{l}\text { Digitalizat } \\
\text { ion }\end{array}$ & $\begin{array}{c}\text { Innovat } \\
\text { ion }\end{array}$ & Training \\
\hline Malaysia & $\sqrt{ }$ & $\sqrt{ }$ & & $\sqrt{ }$ & $\sqrt{ }$ & $\sqrt{ }$ & & $\sqrt{ }$ \\
\hline Singapura & $\sqrt{ }$ & $\sqrt{ }$ & & $\sqrt{ }$ & & & $\sqrt{ }$ & \\
\hline Thailand & $\sqrt{ }$ & $\sqrt{ }$ & $\sqrt{ }$ & $\sqrt{ }$ & & & $\sqrt{ }$ & $\sqrt{ }$ \\
\hline Vietnam & $\sqrt{ }$ & $\sqrt{ }$ & $\sqrt{ }$ & $\sqrt{ }$ & & & & \\
\hline
\end{tabular}

(Source: Organization for Economic Co-Operation and Development (OECD), 2020)

The Indonesian Government has declared the Covid-19 pandemic as a non-natural disaster since mid-March of 2020. According to the Asian Development Bank survey, as of September 16th, 2020, approximately 48,6\% of MSMEs owners in Indonesia were temporarily closed due to the pandemic. It is worrying since MSMEs have contributed to the Indonesian economy by more than $60 \%$. The effect of the Covid-19 experienced by MSMEs has weakened their contribution on tax. The weakened 
contribution in various business sectors on tax is illustrated by the trend of tax revenue performance, which declined drastically in May of 2020.

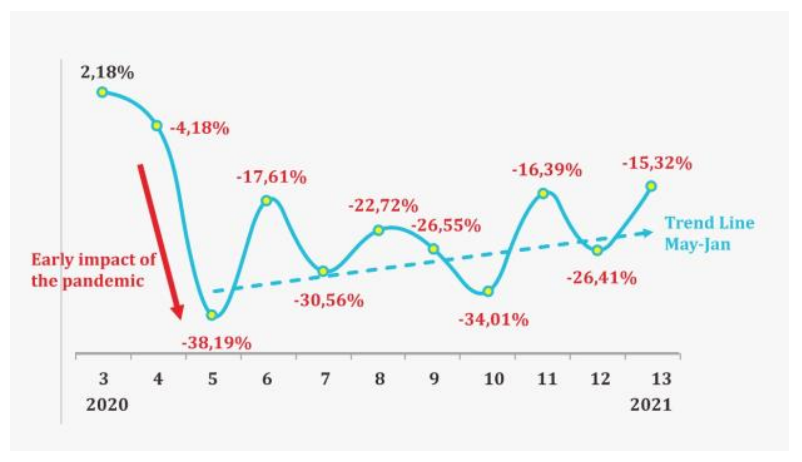

Fig. 2: Monthly growth of tax revenue (yoy) on the same month in the previous year

(Source: the Minister of Finance, the Republic of Ind onesia, 2021)

Currently, the number of MSMEs in Indonesia is approximately 65 million. Due to the large number and their role as tax contributors, the implementation of MSMEs' tax obligations needs to be optimized. One part of its optimizations is by increasing the role of entrepreneurs in the process of policymaking related to tax reporting order. Data gained by the Directorate General of Tax at the Ministry of Finance to the year 2021 show that only around 2 million MSMEs registered as taxpayers and pay their taxes to the state out of a total of 65 million MSMEs (DGT, 2021). The Directorate General of Tax (2018) noted the number of MSMEs taxpayers registered on the tax administration system and tax revenue originating from MSMEs were still far from what they should be.

Furthermore, the Directorate General of Tax of the Ministry of Finance also stated that MSMEs' contribution on tax payment is still low. This circumstance is contradictory to their contribution to Gross Domestic Product. In 2017, the Ministry of Cooperative and Small and Medium enterprises noted the contribution of MSMEs on GDP is around IDR 7.820.282,60 billion or around 60,90\% of the total contribution of business on GDP. Meanwhile, the Directorate General of Tax in 2017 noted that the income tax of MSMEs (final income tax) contributed 2,2\% to the total income tax revenue. Moreover, in 2019, MSMEs contribution to GDP in Indonesia, which was around $60,51 \%$ or around IDR $9.580 .762,7$ billion of the total IDR 15.832.535,40 billion (Statistics Indonesia, 2019). Meanwhile, the utilization of tax incentives for MSMEs as of July 10th, 2020, was around 201.880 MSMEs owners. This amount is still far from the total of MSMEs taxpayers who reported their income tax in 2019, which was around 2,3 million MSMEs taxpayers. MSMEs' contribution on tax-paying, which is lower than MSMEs contribution on GDP, indicates the tax compliance level of MSMEs owners is still low. The big challenge for government is inviting more MSMEs owners to contribute to the country by paying taxes obediently.

More massive efforts are needed to follow up the Covid-19 pandemic effect on the slump in the business sector, the decline of economic growth, and tax revenue in Indonesia. One government effort in the National Economic Recovery is by the policy issuance in the taxation field. The policies in the taxation field to support National Economic Recovery include tax incentive policy. Tax incentive policy aims to help the economic growth during the pandemic. The tax incentive applied by the time this study was conducted the Ministry of Finance Regulation (MFR) No. 82/MFR.03/2021, which is until the end 
of 2021, since the Covid-19 pandemic effect has not subsided. This study focus is only on the tax incentive given to MSMEs for final income tax borne by the government. In this tax incentive, MSMEs taxpayers do not have to need to pay taxes. The government issued tax incentive policies to ease the burden of various business sectors affected by the pandemic. The government committed to helping MSMEs by the National Economic Recovery program in 2020 with a total budget of IDR 114,81 trillion. From this budget, the government gives budget allocation as much as IDR 1.08 trillion for MSMEs tax incentives. In fact, the evaluation result of its implementation in 2020, the realization of tax incentive utilization had only reached 53\% or IDR 0,57 trillion. It means there are still many MS MEs taxpayers who have not enjoyed the tax incentive stimulus.

Tax incentive policy is one of the tax relaxation forms. The author's critical thinking is that tax relaxation is not merely in the form of tax incentive but also the ease of submitting the incentive proposal, the speed of incentive utilization process, the ease of tax reporting, and the extension of the tax incentive period. Through tax relaxation, it is expected to increase the number of business sectors, especially MSMEs, which are assisted. That increase is hoped to be beneficial for MSMEs sustainability. MSMEs sustainability is a reflection of National Economic Recovery. Tax relaxation, which helps MSMEs a lot, will encourage MSMEs taxpayers' compliance. The studies on tax relaxation have not been conducted much. In the previous studies, the referred tax relaxation only included tax incentives and their socialization. The tax incentive is a taxation policy given by the government to certain taxpayers, either individuals or organizations, to provide encouragement and convenience. Tax incentive aims to ensure taxpayers keep obedient in carrying out their taxation obligation both now and in the future. Andrew and Sari (2021) confirmed that the tax incentive socialization of MFR 86/2020 had an effect on tax compliance. In his study, Munandar \& Hamdalah (2020) used the tax relaxation term only referred to the tax incentive. Munandar \& Hamdalah (2020) explained that tax relaxation In Indonesia has been effective, yet it still requires other supporting steps to increase Indonesian economic resilience.

Efforts to improve the level of taxpayers' compliance are relevant to the study of factors supporting the formation of tax compliance. These supporting factors include moral, sanction, and tax compliance. This study uses the attribution theory, which was introduced by Heider (1958) and developed by Kelley (1972). Attribution theory describes one's attitude, which can be influenced by internal and external factors (Nugraheni and Purwanto, 2015). The authors use attribution theory since it is accurate in explaining internal and external factors as an option to increase tax compliance during the pandemic. Based on Attribution theory, moral is the internal factor, and sanction and tax relaxation are the external factors.

This study is different from the previous studies. Its difference and newness are relaxation variables that include tax incentives and the ease of submitting incentive proposal, the speed of incentive utilization process, the extension of tax incentive period through the issuance of the Ministry of Finance Regulation No 82/MFR.03/2021. The urgency of this study is to see the effect of tax relaxation on tax compliance during the Covid-19 pandemic. Besides, it is for proving the extension of the incentive period through the issuance of the Ministry of Finance Regulation, which has been amended/evoked and replaced several times, is still effective in overcoming tax compliance. Subjects of the study are the owners of Micro, Small and Medium enterprises registered at the Department of Cooperative and Micro Enterprise, Magetan Regency, Indonesia. This study result is expected to provide an option to increase tax compliance during the Covid-19 pandemic. 


\section{Literature Review}

\subsection{Tax}

According to Pandiangan (2014:3), tax is a contribution to the state (which can be enforced) which owed by those who are obliged to pay it according to the regulations, without getting back in return that can be directed appointed, and its usage is to finance public expenditures related to state duties to run the government. Law no 28 (2007) defined tax as a mandatory contribution to the state which owed by individuals or corporates which is coercive based on the law, without getting direct compensation and is used for the purposes of the State for the greatest prosperity of the people. Tax is coercive so the government can enforce taxpayers to fulfill their obligation, and if it is violated, the sanction or punishment can be given. Purwono (2010) stated several characteristics embedded in tax are as follows: 1) it is a mandatory contribution of the people to the State; 2) it is collected by the government based on the law, so it is coercive; 3 ) it is without direct compensation; 4) it is used to finance public expenditures related to government implementation; 5) it is used for the people prosperity/ welfare distribution.

\subsection{Attribution Theory}

Attribution theory was introduced by Harold Kelley (1972). It explains when someone observes another's behavior, and meanwhile, that person tries to re-explain the cause of another's behavior, whether it comes from internal or external factors (Nugraheni and Purwanto, 2015). The behavior influenced by internal factors is the in-controlled behavior of the person. Meanwhile, the behavior influenced by external factors is the behavior caused by the impulse outside of the person, either directly or indirectly. This attribution is one process of forming an impression by observing behavior in society, which is based on situational factors. This attribution is given when observing someone's behavior and re-expressing how this behavior can be formed. This behavior is formed whether there is an influence of others or purely from within oneself. This attribution theory is used as the basis to classify the independent variable of the study becomes internal and external factors. According to attribution theory, taxpayer morale is categorized as an internal factor. The moral is formed within an individual's personality, which can influence attitude and behavior, including obedient behavior. Tax sanction and tax relaxation are categorized as external factors. Sanction and tax relaxation are factors outside of the individuals which can influence their attitude directly or indirectly.

\subsection{Tax Compliance}

Tax compliance is the impulse that comes within a person sincerely to carry out his taxation obligation (Amah, 2019:3). According to Tahar (2014), the compliance in taxation triggers tax payers to be responsible to God, government, and society to fulfill all rights and obligations as taxpayers. This taxpayer compliance is a conscious behavior of his tax obligations in accordance with the provision of taxation laws applied in Indonesia. Amah (2019: 39) stated taxpayer compliance consists of: 1) Formal compliance is a state where the taxpayer fulfills his obligation formally according to the provision of taxation laws. Formal compliance reflects obligation fulfillment of tax deposit and reporting according to pre-determined schedule; 2) Material compliance more emphasizes its substantial aspect, that is, the amount of tax payment in accordance with the provisions. It means the calculation and tax deposit have been correct. The high level of taxpayer compliance will have an impact on the improvement of society's welfare level.

\subsection{Taxpayer's Moral}

Mardiasmo (2011) stated that society is reluctant to pay taxes can be triggered by society's moral and intellectual development, complicated taxation system, and control system which is properly implemented. 
Moral compliance is an individual motivation owned by a professional tax but possibly not owned by other professional tax. Widodo (2010: 9), defined tax moral as a motivation which emerged within the individual to paid taxes. This motivation can emerge from moral obligation or belief to contribute to the State by paying taxes, or an individual's willingness to pay taxes. Based on the above definition, it can conclude that tax moral is a motivation coming from within the individuals or taxpayers to pay their taxation obligation. The self-assessment system adopted in Indonesian taxation gives taxpayers the freedom to calculate, pay taxes owed, report, and be responsible for their own tax obligations. Self-assessment system can create an opportunity for taxpayers to be obedient or disobedient. If taxpayers hold a good tax moral, the compliance level will be high even though there is an opportunity for being disobedient. The tax moral concept helps solve the tax compliance puzzle, explaining the high level of tax compliance in many countries by a very low prevention level (Torgler dan Schneider, 2007).

Taxpayers' moral is a strong encouragement within the individuals, who believes that tax obligation is mandatory which should be fulfilled by every individual for the sustainability of the governance and the development of the Republic of Indonesia (Pertiwi, 2017). Tax moral is an internal motivation from within the taxpayers to comply with their taxation obligation so they could contribute voluntarily to the state. Tax moral is a determinant of one's compliance level in complying taxation regulations (Cahyonowati, 2011). Pertiwi (2017) confirmed moral has a significant positive effect on tax compliance. Previous studies (Cahyonowati, 2011; Sriniyati, 2020) agreed that moral has a significant positive effect on the formation of tax compliance. It is because paying taxes is an obligation that cannot be separated from the state of taxpayers. Moral can lead to self-motivation in the society to increase the compliance in paying taxes. The good tax moral can be in the form of an intention not to escape the obligation to pay taxes both legally and illegally. However, the study of Salman and Farid (2008) as well as (Sani and Habibie, 2017) found a different result that is taxpayer's moral has not to effect on taxpayer compliance. Tax moral factor always becomes an interesting study to reveal tax compliance of MSMEs owners during the Covid-19 pandemic. The Covid-19 pandemic has had a negative impact on the cash flow of the majority of MSMEs. In that condition, there are two possibilities that will emerge, that is the moral keeps playing an important role in moving the individual of MSMEs owners to keep carrying out the taxation obligation in accordance with the applicable laws and regulations or vice versa.

\subsection{Sanction}

The orientation of the good moral tax is the formation of voluntary tax compliance. However, the existing fact shows that tax compliance of the majority of taxpayers is still coerced compliance. Taxpayers are obedient in order to avoid tax sanctions (Pertiwi, 2017). Tax sanction is the guarantee that the taxation norm will comply. Mardiasmo (2019) explained that tax sanction is a deterrent so taxpayers will not break the taxation norms. The Taxation General Provision and Procedure Law no 28 the Year 2007 explained the taxpayers could be subject to administrative fines, interest, and criminal sanctions. Tax sanctions will be imposed on taxpayers if they violate the regulations of tax laws. Taxpayers consider the sanctions they receive will add to the burden they have to bear even more. Taxpayers will attempt to fulfill their taxation obligation to avoid sanctions. Sanctions in the form of interest and administration fines will disadvantage the taxpayers themselves. They have to spend an even higher cost. Disobedient taxpayers are worsening the company's cash flow, especially if it is related to their condition during the Covid-19 pandemic. Tax sanction encourages taxpayers to be obedient and punctual in carrying out their taxation obligation in accordance with the specified time. Several studies (Muliari \& Setiawan, 2011; Alfasadun, 2016; and Arisandy, 2017) proved that tax sanction has a significant effect on taxpayer compliance. There are also inconsistent results. Several studies show that there is no effect of tax sanction on taxpayer compliance because the sanctions given to 
taxpayers are not strict (Ermawati and Afifi, 2018). Besides, some taxpayers assume sanctions are merely a regulation formality.

\subsection{Tax Relaxation}

In some previous studies, tax relaxation only refers to the tax incentive. The tax incentive is in the form of positive persuasion, which can encourage taxpayers to comply with the relevant laws and taxation regulations (Slemrod, 1992; Smith, 1992). In Indonesia, the tax incentive is a policy in the taxation field to support National Economic Recovery. This policy aims at helping to move the declining state's economic growth due to the Covid-19 pandemic. Tax incentive policy is written in the Ministry of Finance Regulation no 86 Year 2020. This regulation is the revision of the previous regulation, that is MFR no 44 Year 2020 on tax incentives for taxpayers affected by the Covid-19 pandemic. MFR no 86 Year 2020 revised by MFR no 110/MFR.03/2020, then replaced with MFR no. 9/MFR.03/2021 as lastly revised by MFR No. 82/MFR.03/2021.

MFR no 44 Year 2020 includes five tax incentive policies, namely, Income Tax Article 21 incentive, Income Tax Article 22 on import, Income Tax Article 25 on installment payment, MSMEs tax and Value Added Tax. Based on the Ministry of Finance Regulation no 44 Year 2020, the government will bear final income tax of MSMEs based on Government Regulation no 23 Year 2018 concerning income tax on income from businesses received or obtained by taxpayers who have a certain gross turnover until December 2020. Tax incentive currently is extended through MFR No. 82/MFR.03/2021 that is until the end of 2021, since the impact of the Covid-19 pandemic has not subsided. In contrast to MFR no. 44/MFR.03/2020, on MFR No. 82/MFR.03/2021 03/2021 there are 6 tax incentive policies including: a) Income Tax incentives article 21 borne by the Government; b) MSME tax incentives or final Income Tax borne by the Government; c) Final Income Tax on construction services is borne by the Government; d) Income tax article 22 imports e) income tax instalment incentives article 25 for taxpayers who are engaged in one of 216 certain business fields; f) Value Added Tax incentives. The focus of the authors is tax incentive given to MSMEs final income tax borne by the Government. Ayuba et al., (2006) agreed that tax incentives as a form of positive persuasion for taxpayers to comply with the applicable laws and tax regulations.

\subsection{Hypothesis}

Tax moral is a motivation within an individual (internal) to pay taxes (Pertiwi, 2017). The moral is a value or principle on right or wrong, which is built in a person by the influence of family and social environment. Wanzel (2004) concluded that moral, ethics, and norm of taxpayers greatly influence their behavior. Tax morality is a positive motivation derived from within to obey and comply with tax regulations. Therefore, when a person has a good and positive moral, his behavior will be good, including his obedient behavior on tax regulations. Alm and McClellan (2012) found that tax moral has a significant positive effect on tax reporting, which is a part of tax compliance. In line with the study of Alm and McClellan (2012), several studies (Cummings et al., 2004; Torgler et al., 2017; Sjoberg et al., 2019; Noviyanti and Azzam, 2021), Alm et al., 2021) also showed that tax moral has a significant positive effect on tax reporting which is a part of tax compliance.

\section{$\mathrm{H}_{1}$ : Tax moral has a positive effect on tax compliance of MSMEs owners.}

Tax sanction is applied to create a deterrent effect on taxpayers who violate the tax laws regulations. There are binding tax sanctions in the tax law and all kinds of regulations embedded in it. Mardiasmo (2011) explained that tax sanction is a guarantee that the provisions of tax law (tax norms) will be complied with, adhered to, and obeyed. The existence of tax sanctions is required to create taxpayer awareness to comply 
with the applicable tax regulations. Strict rules of the consistent implementation of tax sanctions will definitely be able to solve the issues of taxpayer compliance. It is in line with the result of several studies (Arisandy, 2017; Rapoport, Mendez, and Scartascini, 2020; Castro and Scartascini, 2014; Lopez and Scartascini, 2019) which agreed that the use of intervention on behavior, one of which is tax sanction would decline tax avoidance. Thus, it means sanctions will affect the formation of taxpayer compliance.

H2: Tax sanction has a positive effect on tax compliance of MSMEs owners.

Tax relaxation given by the government is expected to increase the number of business sectors, especially MSMEs, which are assisted. This increase is hoped to be the stimulus for the sustainability of MSMEs. The sustainability of MSMEs reflects the National Economy Recovery. Tax relaxation, which eases MSMEs, will encourage the taxpayer compliance of MSMEs. In the previous studies, there were more studies using tax incentive variables to describe tax relaxation. Brockmann et al. (2016) found that incentives in the form of rewards given to taxpayers will have an effect on the increase of tax compliance. It is in line with previous studies (Tung and Cho, 2001; Ullah, 2016; Ayuba et al., 2016; Munandar\& Hamdalah, 2020; Riyanto and Mudara, 2021). Based on this logic, the proposed hypothesis is:

H3: Tax relaxation has a positive effect on the tax compliance of MSMEs owners.

\section{Research Methodology}

The population in this study is all MSMEs owners both in service and trade sectors registered at the Department of Cooperative and Micro Enterprise, Magetan Regency, Indonesia. The authors chose Magetan Regency because that region has many MSMEs owners in various businesses, including the culinary sector, leathercraft, and other sectors. The technique used for the sampling is Purposive Sampling. The authors applied MSMEs sampling criteria in accordance with the MSMEs Laws in 2008. The author's consideration using the MSMEs Laws in 2008 is to collect samples according to the interests of authors and to distinguish the characteristics of each sample. The sampling criteria used include a) The samples are Micro, Small, and Medium businesses; b) The micro-business category is having a net worth/working capital of a maximum of IDR 50,000,000 and annual sales of a maximum of IDR 300,000,000; c) The Small business category is having a net worth/capital of more than IDR 50,000,000,- up to a maximum of IDR 500,000,000 and annual sales of more than IDR 300,000,000 up to a maximum of IDR 2,500,000,000; d) The medium business category is having a net worth/business capital of more than IDR 500,000,000 up to a maximum of IDR $10,000,000,000$ and annual sales results of more than IDR 2,500,000,000 up to a maximum of IDR $50,000,000,000$. Sources of data in this research consist of primary and secondary data. Primary data is MSME taxpayers' perception data about taxpayer compliance, morale, sanctions, and tax relaxation. Primary data was obtained by distributing questionnaires to respondents. The Google form link containing the questionnaire statement is distributed via the WhatsApp group of MSMEs owners. The distribution of the questionnaires was carried out in mid-July 2021. Secondary data is the number of MSME owners obtained from the Department of Cooperatives and Micro Enterprises, Magetan Regency.

This study uses 1 dependent variable, namely the taxpayer compliance of MSMEs (Y) and 3 independent variables, namely moral (X1), sanction (X2), tax relaxation (X3). Tax Compliance is an impulse that arises from within a person to carry out his tax obligations in accordance with the applicable laws and regulations. The study uses several indicators to identify taxpayer compliance which consists of: being obedient in reporting himself to the tax office, being obedient in depositing Annual Tax Return punctually, being obedient in calculating tax payable, being obedient paying tax arrears (if one has arrears) (Rahayu, 
2013:139). The moral is a self-motivation of a person who will define his attitude in fulfilling his taxation rights and obligations. The indicators to measure moral variable was adopted by Nabila (2018). Those are a violation of existing ethics, guilt feeling if taxpayers have not fulfilled their obligations, the life principle on taxation. Sanction is a mechanism to improve compliance with regulations. This study uses the perception of taxpayers on sanction measured by indicators: severe tax sanction for violators, tax sanction as a means to educate taxpayers, imposition of tax sanction without tolerance. Those indicators were adopted by (Muliari \& Setiawan, 2011). Tax Relaxation is freedom given by the government for taxpayers in carrying out their taxation obligations. The authors use the perception of taxpayers on tax relaxation. The developed indicators consist of: the provision of tax incentive policy by the government, the ease of submitting incentive proposals, the speed of incentive utilization process, the extension of the tax incentive period, the ease of tax reporting. The independent and dependent variables measurement used the Likert Scale with a range of 1-5 with answer choices for statements including strongly disagree, disagree, neutral, agree, and strongly agree. Indicators to measure each variable developed into 5 statements in the questionnaire.

The authors use multiple linear regression analysis by SPSS v.16 to analyze data. Before that, the authors processed the data so descriptive statistics could be presented. The authors also conducted a classical assumption test as a requirement of multiple linear regression analysis. Classical assumption test consists of normality test, multicollinearity test, heteroscedasticity test, and autocorrelation test. Equation of Multiple Linear Regression is as follows:

$$
\mathrm{Y}=\alpha+\beta 1 \mathrm{X} 1+\beta 2 \mathrm{X} 2+\beta 3 \mathrm{X} 3+\mathrm{e}
$$

\section{Results and Discussions}

\subsection{Statistic descriptive}

Table 3: Descriptive Statistics

\begin{tabular}{lrrrrrrrr}
\hline & N & Range & Minimum & Maximum & Sum & Mean & $\begin{array}{c}\text { Std. } \\
\text { Deviation }\end{array}$ & Variance \\
\hline X1_Moral & 95 & 13 & 10 & 23 & 1694 & 17,83 & 2,704 & 7,312 \\
\hline X2_Sanction & 95 & 15 & 10 & 25 & 1785 & 18,79 & 2,993 & 8,955 \\
\hline X3_Relaxation & 95 & 15 & 10 & 25 & 1704 & 17,94 & 3,202 & 10,251 \\
\hline $\begin{array}{l}\text { Y_Tax } \\
\text { Compliance }\end{array}$ & 95 & 15 & 10 & 25 & 1931 & 20,33 & 2,711 & 7,350 \\
\hline $\begin{array}{l}\text { Valid N } \\
\text { (listwise) }\end{array}$ & 95 & & & & & & & \\
\hline
\end{tabular}

(Source: Da ta processed by authors)

These descriptive statistics provided an overview of the data for each variable. Table 3 shows that the maximum value for moral was 23 , sanction was 25 , tax relaxation was 25 , tax compliance was 25 , and each minimum value for moral, sanction, tax relaxation and tax compliance was 10 . This means that there are gaps or deviations in the respondent's response score on moral, sanction, tax relaxation, and tax compliance. However, the mean value of respondents' responses to morals is 17,83 , which means that the moral level based on respondents' responses is good. The mean value of sanctions is 18,79 , which means that respondents assume that tax sanctions are dominant in influencing their compliance. Each of relaxation and tax compliance has a good level. Then to conduct further tests, the authors ensure data had been standardized and fulfilled classical assumption test. 


\subsection{Classical Assumption Test}

The authors conducted a classical assumption test which included normality, multicollinearity, autocorrelation, and heteroscedasticity tests. When testing autocorrelation, the authors obtained the result that there is autocorrelation in the research model. This is a table of autocorrelation test results:

Table 4: Autocorrelation Test

\begin{tabular}{llll}
\hline $\mathrm{Du}$ & $\mathrm{Dw}$ & 4-Du & Description \\
\hline 1,7316 & 1,087 & 2,2684 & there is autocorrelation \\
\hline
\end{tabular}

(Source: Data processed by authors)

The research model is free from autocorrelation problems if the DW (Durbin Watson) value is between $\mathrm{Du}$ and 4-Du values. The autocorrelation test results show the value of Dw below the value of Du. The conclusion is that there is autocorrelation. The authors conducted data transformation and Cochrane Orrcut to overcome autocorrelation. After the transformation, the amount of data used was reduced to 94 samples. The following are the results of the classical assumption test after the transformation and Cochrane Orrcut.

Table 5: One Sample Kolmogorov - Smirnov Test

\begin{tabular}{lll}
\hline $\mathrm{N}$ & Asymp. Sig. (2-tailed) & Description \\
\hline 94 & 0,715 & normally distributed \\
\hline
\end{tabular}

(Source: Data processed by authors)

Table 5 indicates the findings of normality by One Sample Kolmogorov - Smirnov Test. The normality issue appears when the value of sig. less than 0,05 (Priyatno, 2011: 282). The findings show the value of Asymp. Sig (2-tailed) is more than 0,05 which is 0,715. This indicates that the residual data in the regression model is normally distributed.

Table 6: Autocorrelation Test (after transformation)

\begin{tabular}{llll}
\hline $\mathrm{Du}$ & $\mathrm{Dw}$ & $4-\mathrm{Du}$ & Description \\
\hline 1,7306 & 2,219 & 2,2694 & there isn't autocorrelation \\
\hline
\end{tabular}

(Source: Data processed by authors)

Table 6 presents the finding of the Durbin Watson (DW) value of the Autocorrelation Test. These finding also proves that in the research model there is no autocorrelation because the DW value is between Du and 4-Du value (Priyatno, 2011: 292).

Table 7: Multicollinearity Test

\begin{tabular}{lccl}
\hline Variables & Tolerance & VIF & Description \\
\hline Lag_X1 & 0,982 & 1,018 & there isn't multicollinearity \\
\hline Lag_X2 & 0,938 & 1,066 & there isn't multicollinearity \\
\hline Lag_X3 & 0,944 & 1,059 & there isn't multicollinearity \\
\hline
\end{tabular}

(Source: Data processed by authors)

Table 7 presents the findings of the tolerance and the VIF values for the research variables of the regression model. The finding also proves that the research model is a fit regression model because it does not have multicollinearity problems, in which the tolerance value is more than 0,10 and the VIF value is less than 10 (Priyatno, 2011: 288). 
ISSN: $2247-6172$

Review of Applied Socio- Economic Research

(Volume 22, Issue 2/2021), pp. 21 -36

URL: http://www.reaser.eu e-mail: editors@reaser.eu

Tabel 8. Heteroscedasticity Test

\begin{tabular}{cccccc}
\hline & & $\begin{array}{c}\text { Unstandardized } \\
\text { Residual }\end{array}$ & Lag_X1 & Lag_X2 & Lag_X3 \\
\hline $\begin{array}{c}\text { Spearman's rho Unstandardized } \\
\text { Residual }\end{array}$ & Sig. (2-tailed) &. & 0,896 & 0,280 & 0,686 \\
\hline Lag_X1 & Sig. (2-tailed) & 0,896 &. & 0,391 & 0,452 \\
\hline Lag_X2 & Sig. (2-tailed) & 0,280 & 0,391 &. & 0,067 \\
\hline Lag_X3 & Sig. (2-tailed) & 0,686 & 0,452 & 0,067 &. \\
\hline & (Source: Data processed by authors) & & &
\end{tabular}

Table 8 shows the testing of heteroscedasticity by the Spearman test. The heteroscedasticity issue appears when the significance value of correlation between research variables and Unstandardized residuals is less than 0,05 (Priyatno, 2011: 297). All the findings of significance value of correlation between research variables and Unstandardized residuals more than 0,05 . The conclusion is that there is no heteroscedasticity in the regression model.

\section{Multiple Linear Regression Analysis}

From the result of processing data, the equation of multiple linear regression is as follows:

$\mathrm{Y}=6,913+0,009 \mathrm{X} 1+0,215 \mathrm{X} 2+0,189 \mathrm{X} 3$

The multiple linear regression equation shows that tax sanctions are the most dominant variable affecting the increase in MSME taxpayer compliance. This reflects that MSME taxpayer compliance is formed because of the fear of sanctions. Compliance formed is compliance due to coercion (enforced tax compliance).

\subsection{Hypothesis Test Result}

Table 9: Summary Model Table

\begin{tabular}{crrrr}
\hline Model & $\mathrm{R}$ & R Square & Adjusted R Square & $\begin{array}{c}\text { Std. Error of the } \\
\text { Estimate }\end{array}$ \\
\hline 1 & $0,424^{\mathrm{a}}$ & 0,180 & 0,153 & 2,27855 \\
\hline
\end{tabular}

(Source: Data processed by authors)

The contribution of the independent variables (moral, sanctions, tax relaxation) affects the dependent variable (MSMEs Taxpayer Compliance) by $15,3 \%$.

Table 10: F Test Result

\begin{tabular}{llrrrrl}
\hline & Model & Sum of Squares & df & Mean Square & F & Sig. \\
\hline 1 & Regression & 102,551 & 3 & 34,184 & 6,584 & $0,000^{\text {a }}$ \\
\cline { 2 - 7 } & Residual & 467,263 & 90 & 5,192 & & \\
\cline { 2 - 7 } & Total & 569,814 & 93 & & & \\
\hline
\end{tabular}

(Source: Data processed by authors)

The $\mathrm{F}$ test showed the goodness of fit statistic value is 0,000 . That value is less than 0,05 . It means the model is able to predict its observation value. The research model is right.

Table 11: $t$ Test Result

\begin{tabular}{lll}
\hline Model & $\mathrm{T}$ & Sig. \\
\hline
\end{tabular}




\begin{tabular}{llll}
\hline 1 & (Constant) & 5,820 & 0,000 \\
\cline { 2 - 4 } & Lag_X1 & 0,103 & 0,918 \\
\cline { 2 - 4 } & Lag_X2 & 2,896 & 0,005 \\
\cline { 2 - 4 } & Lag_X3 & 2,579 & 0,012 \\
\hline
\end{tabular}

(Source: Data processed by authors)

The results of t-test reflect that moral has no effect on tax compliance of MSMEs owners. The significance value of the moral variable is 0,918 (more than 0,05). Sanction affects the tax compliance of MSMEs owners. The value of $t$. count of sanction $>$ t. table $(2,896>1,98667)$, with the significance value is $0,005(<0,05)$. Tax relaxation affects the tax compliance of MSMEs owners. The value of $t$ count of the tax relaxation $>$ t. table $(2,579>1,98667)$. The significance value is $0,005(<00,5)$. In conclusion, $\mathrm{H} 1$ is rejected, $\mathrm{H} 2$ and $\mathrm{H} 3$ are accepted.

\section{Discussion}

\subsection{The effect of moral on tax compliance of MSMEs owners.}

The hypothesis which states tax moral has a positive effect on tax compliance of MSMEs owners is not significant. Hypothesis 1 (H1) was rejected. Tax moral variable has no effect on the tax compliance of MSMEs owners. The Covid-19 pandemic has had a bad effect on the cash flow of the majority of MSMEs. This condition raises the fact that tax moral cannot underlie the behavior of taxpayers complying with their tax obligations. There are other considerations, especially in cash flow efforts becoming more important and harder than behaving obediently. This study's result supports the studies of Salman and Farid (2008). This study is not in line with the studies of (Lisie, 2015; Alasfour et al., 2016; Horodnic, 2018; Ubaidillah \& Amah, 2020), which stated that the improvement of tax moral would be followed by the improvement of taxpayer compliance in paying taxes.

\subsection{The effect of sanction on tax compliance of MSMEs owners.}

The hypothesis which states tax sanction has a positive effect on tax compliance of MSMEs owners is significant. Hypothesis $2(\mathrm{H} 2)$ was accepted. According to the theory of compliance, one tends to obey the laws which they consider appropriate and consistent with their internal norms. Tax sanction is included in normative commitment through legitimacy. One obeys the regulations since the legislator has the authority to dictate or bind behavior.

In attribution theory, tax sanction is an external cause for taxpayer compliance. Increasingly stringent sanctions mean that the external influence on taxpayer compliance to complete their tax obligations is also high. This study is in line with the studies conducted by Setiyoningrum (2015), which showed that there is an effect of tax sanction on tax compliance. It is supported by the studies of (Alfasadun 2016; Arisandy, 2017; Rapoport, Mendez, \& Scartascini, 2020; Castro \& Scartascini, 2014; Lopez \& Scartascini, 2019; Dewi et al., 2020), but it is contrary to the studies' result of (Ermawati \& Afifi, 2018; Andrew \& Sari, 2021).

\subsection{The effect of tax relaxation on tax compliance of MSMEs owners.}

The hypothesis which states tax relaxation has a positive effect on tax compliance of MSMEs owners is significant. Hypothesis 3 (H3) was accepted. The Covid-19 pandemic has had a huge impact on MSMEs. The pandemic causes the emergence of several issues for MSMEs, such as the decreased demand, the difficulties of product marketing, the access limitation of production materials. This condition further causes the level of sales/business turnover to decline. The decline of the business turnover will be disturbing the company's cash flow. Tax relaxation is a policy to stimulate the sustainability of MSMEs (Indaryani et al., 
2020). The government helps to ease the burden of MSMEs by tax relaxation. It will support the taxpayer compliance of MSMEs. This study is in line with the studies of (Smith and Stalans, 1991; Munandar\& Hamdalah, 2020; Tung \& Cho, 2001; Ullah, 2016; Ayuba et al., 2016; Andrew \& Sari, 2021; and Leong et al., 2020) but it is contrary to the study of Dewi et al. (2020). Tax relaxation is another option besides tax sanction as an effort to increase taxpayer compliance on MSMEs owners. Tax relaxation in the form of MSMEs' final tax income borne by the government gives the impact and benefits of easing the burden of MSMEs. Tax relaxation also includes the ease of submitting incentive proposals, the speed of the incentive utilization process, the ease of tax reporting, and the extension of the tax incentive period, which support the implementation of a self-assessment system on MSMEs taxpayers. The extension of the tax incentive period is an opportunity for MSMEs owners who are in the previous period, had not taken advantage of this tax incentive. This is in accordance with data from MSMEs owners of Magetan Regency, who took advantage of tax incentives in 2021 to increase compared to 2020.

\section{Conclusion}

The result of this study showed that the tax sanction variable is the dominant variable that affected the tax compliance of MSMEs owners in Magetan, Indonesia. It indicated tax compliance of MSMEs owners is enforced tax compliance. As another option, a solution to keep maintaining MSMEs owners' tax compliance in the Covid-19 pandemic is tax relaxation. Tax relaxation is expected to foster voluntary tax compliance. Tax moral variable has no effect on the tax compliance of MSMEs owners. During the pandemic, the cash flow business condition has become an important and burdening consideration for MSMEs owners compared to being obedient. The extension of the incentive period through the issuance of the Ministry of Finance Regulation, which has been amended/ evoked and replaced several times, is effectively overcoming tax compliance.

This study has several limitations. The first limitation, the sample of this study only consisted of MSMEs taxpayers in one regency. Therefore, the results of the study cannot be generalized to MSMEs taxpayers in other regions. The second limitation is that collecting data was conducted by distributing Google form questionnaire on WhatsApp group may seem biased. It is because the collected information is personally related to tax compliance and the moral of each person. Out of those limitations, the next study's suggestion is to conduct the study by combining the method of collecting data, so the data obtained is more representative. The beneficial potential for further studies is to expand MSMEs taxpayers in several other regions and compare MSMEs tax compliance of each region. The suggested data collection method is a combination between questionnaires and face-to-face interviews.

\section{References}

[1] Ala sfour, F., Samy, M. and Bampton, R. (2016). The Determinants of tax mo rale and tax compliance: e viden ce from Jordan. Advanced in Ta xation, 23, 125-171. Doi: 10.1108/S1058-749720160000023005.

[2] Alfasa dun. (2016). Coaching taxpayers policy and tax penalties against tax complia nce. Jurnal Akuntansi.

[3] Alm, J. and C. McClellan. (2012). Tax Morale and Tax Complia nce from the Firm's Perspektif. Kyklos, Vol. 65 No. 1,1-17.

[4] Alm, J., K. Blaufus, M. Fochmann, E. Kirchler, P.N.C. Mohr, N.E. Olson, B. Torgler (2021). Tax Policy Mea sures to Combat the SARS-CoV-2 Pandemic and Considerations to Improve Tax Compliance: A Behavioral Perspective. Tulane Economics Working Paper Series, 2102.

[5] Amah, N. (2019). Modernisasi Sistem Adminisrasi \& Tax Amnesty: Faktor Pendukung Kepatuhan Pajak. Madiun: UNIPMA Press. 
[6] Andrew, R. dan D.P. Sari(2021). Insentif PMK 86/2020 Di Tengah Pandemi Covid 19: Apakah Mempengaruhi Kepatuhan Wajib Pajak UMKM Di Surabaya? Jurnal Akuntansi dan Pajak, Vol. 21, No. 2, 349-366.

[7] Arisandy, N. (2017). Pengaruh Pemahaman Wajib Pajak, Kesadaran Perpajakan, dan Kepatuhan Wa jib. Ju rnal Ilmiah Ekonomi Dan Bisnis, 14(1), 62-71.

[8] Ayuba, A., N. Saad,Z.Z. Arifin. (2016). Perceived Service Orientation, Economic Factors, PsychologicalFactors and Tax Compliance: EvidenceFrom Nigerian SMEs. Malaysian Management Journal, Vol.20, 41-57.

[9] Brockmann H., P. Genscheland L. Seelkopf. (2016). Happy Taxation: increasing Tax Complia nce Through Positive Rewards? Journal of Public Policy, Vol. 36 Issue 3.

[10] Cahyonowati, N. (2011). Modelmoral dankepatuhan perpajakan: wajib pajak orang pribadi. Jurnal Perpajakan, 15(2), 161-177.

[11] Castro,L., \& Scartascini, C. (2014). The devil is in the details: Policy design lessons from field experiments in the pampas. (IDB Policy Brief No. 232. Inter-American DevelopmentBank, Washington, DC.)

[12] Cummings, R.G., J.M. Vazquez, M. McKee, B. Torgler. (2004). Effects of Tax Morale in Tax Compliance: Experimental and Survey Evidence. RePEc.

[13] Dewi, S., Widya sari, dan Na taherwin. (2020). PengaruhInsentif Pajak, Tarif Pajak, Sa nksi Pajak dan Pelayan Pajak Terhadap Kepatuhan Wajib Pajak Selama Masa Pandemi Covid-19. JurnalEkonomi dan Manajemen, Vol. 9, No. 2.

[14] Ermawati, N. dan Z. Afifi. (2018). Pengaruh Pengetahuan Perpajakan dan Sanksi Perpajakan terhadap Kepatuhan Wajib Pa jak dengan Religiu sitas sebagai variabel Pem derasi. Seminar Na sional MultiDisiplin Ilmu dan Call For Papers.

[15] Indaryani, M., N. Andriyani, S. Mulyani: Dampak Covid-19 dan Pemanfaatan Insentif Pajak terhadap Keberlangsungan Usaha pada UMKMTenun Troso Jepara. Jurnal Manajemen dan Keuangan, Vol. 9, No. 3.

[16] K.W. Smith and L. J. Stalans. (1991). Encouraging Tax Compliance with Positive Incentives: A Conceptul Fra mework and Research Directions. Law and Policy, Vol. 13, issue 1, p.35-53.

[17] Lopez-Luzuriaga, A., \& Scartascini, C. (2019). Compliance spillovers a cross taxes: The role of penalties and detection. Journal of Economic Behavior Orga nization , 164 ,518-534.

[18] Mardiasmo. (2011). Perpajakan, Edisi Revisi. Jogja karta: Penerbit Andi.

[19] Mardiasmo. (2019). Perpajakan, Edisi 2019. Jogjakarta: Penerbit Andi.

[20] Muliari\& Setiawan(2011). Pengaruh persepsitentang sanksi perpajakan dan kesadaran wajib pajak pada kepa tuhan pelaporan wajib pajak orang pribadidikantor pelayanan pajak pratama denpasar tim ur. Jurnal Akuntansi, 1-23.

[21] Munandar \& M. Hamdalah. (2020). (Analysis The Effectiveness Of Tax Relaxation Due To Covid-19 Pa nde my On Indonesian Economic Defense). Lex Scientia Law Review 4(1), 133- 142. DOI : https://doi.org/10.15294/lesrev.v4i1.38631

[22] Noviyantidan S. M.F. Azzam. (2021). The Impact of Covid-19 Pandemic on Taxpayer's Compliance of MSMEs in Palembang. Widyakala Journal, Vol. 8, No. 1.

[23] Nugraheni, A. D. dan Purwanto. (2015). Faktor-faktoryang mempengaruhi kepatuhan ( Studi Empiris Pada Wajib Pajak di Kota Magelang ). 4, 1-14.

[24] Pandiangan, L. (2014). Administrasi Perpajakan. Jakarta: Penerbit Erlangga.

[25] Pertiwi, I.F.P. (2017). Moral Pajak: sebuah opsi penin gkatan kepatuhan pajak masyarakat muslim. Jural Ekonomi Dan Bisnis Indonesia , 1(1), 125-135. 
ISSN: $2247-6172$

Review of Applied Socio- Economic Research

(Volume 22, Issue 2 2021), pp. 21 -36

URL: http://www.reaser.eu e-mail: editors@reaser.eu

[26] Priyatno, D. (2011). SPSS Analisis Statistik Data, Lebih Cepat, Efisien, dan Akurat. Yogyakarta: Mediakom.Rahayu, S.K. (2013). Perpajakan Indonesia: Teori dan Teknis Perhitungan. Jakarta:Graha Ilmu.

[27] Rapoport, N., Méndez, A., \& Scartascini, C. (2020). Behavioral insights for foresighted public fin ance. (IDB Policy Brief No. 324. Inter-American Development Bank, Wa shington, DC.)

[28] Riyanto dan N. A. H. P. Mudara.(2021). Kebijakan FiskaldalamPandemiCovid-19: Dampak dan Tantangan Penerimaan Pajak Di KPP Wajib Pajak Besar Dua. ScientaxJurnalkajian Ilmiah Perpajakan Indonesia, Vol. 2 , No. 2.

[29] Sa lman, K.R and Farid, M. (2008). Pengaruh sikapdan moral pajak pada industri perbankan di Sura baya. Journal of Economic, Business \& Accountancy.

[30] Sani, A. dan A. Habibie. (2017). Pengaruh Moral Wajib Pajak, Sikap Wajib Pajak dan NormaSubjektif te rhadap Kepatuhan Pajak melalui Pemahaman Akuntansi. Jurnal Ilman, Vol. 5, No. 2, 80-96. https://doi.org/10.31227/osf.io/3h48eHerryanto.(2013). Pengaruh kesadaran wajib pajak, ke gia tan so sialisa si perpajakan dan pemeriksaan pajak terhadap penerimaan pajak. Jurnal Perpajakan, 1(1), 125-135.

[31] Setiyoningrum.(2015). Analisis pengaruh sosialisasi perpajakan, kualitas pelayanan fiskus dan sanksi perpajakan terhadapkepatuhan wajib pajak orang pribadi di KPP Manado. Jurnal Perpajakan.

[32] Sjoberg, F.M., J. Mellon, T. Peix oto, J. Hemker, L.L. Tsai. (2019). Voice and Punishment A Global Survey Experiment on Tax Morale. World Bank Governance GlobalPractice.

[33] Slemrod. (1992). Do Taxes Matter? Lessons from the 1980's. American Economic Review. American Eco nomic Association, Vol. 82, No. 2, 250-256.

[34] Smith, S. (1992). Taxation and Environment: A Survey. Fiscal Studies, Vol.13, No. 4, 21-57.

[35] Sriniyati. (2020). Pengaruh Moral Pajak, Sanksi Pajak, dan Kebijakan Pengampunan Pajak Terhadap Kep atuhan Wajib Pajak Orang Pribadi. Jurnal Akuntansi, Ekonomi dan Bisnis, Vol 8., No 1. DOI: https://doi.org/10.30871/jaemb.v8i1.1913

[36] Tahar A. (2014). Pengaruh faktor internal da n faktor eksternal terhadap kepatuhan wajib pajak. Jurnal Akuntan si, 15(1), 56-67.

[37] Torgler, B., M. Schaffner, and A. Macintyre. (2017). Tax Compliance, Tax Morale a nd Governance Qu ality. downloaded on https://ideas.repec.org/cgibin/htsearch?q=Tax+Compliance\%2C+Tax+Morale\%2C+and+Governance+Quality August 12th, 2021.

[38] Torgler, B, dan F. Schneider. (2007). The Impact of Tax Morale and Institutional Quality on the Shadow Economy. Germany: The Institute for the Study of Labor (IZA). Discussion Paper(DP). No. 2541.

[39] Tung, S., and Cho, S. (2001). Determinants of regional investment decisions in China: An econometric m od el of tax incentive policy. Review of Quantitative Finance and Accounting, 17 (2), $167-185$. doi:10.1023/A:101795721627

[40] Ubaidillah, Moh.dan N. Amah. (2020). The Role of Administrative Modernization in Sha ping Tax Moral to Increase Taxpayer Compliance: Case Study in Madiun, Indonesia. Semestre Economico, 23 (55), pp 221-238.

[41] Ullah, N. (2016). The rela tionship of government revenue and government expenditure: A case study of Malay sia. MPRA paper no. 69123, 1-20.

[42] The Minister of Finance, the Republic of Indonesia. (2021). APBN Kita Kinerja dan Fakta. Edition January 2021

[43] The Minister of Finance, the Republic of Indonesia. (2021). Regulation of the Minister of Finance Number 82/PMK.03/2021 concerning Amendments to Regulation of the Minister of Finance Nu mber 9/PMK.03/2021 concerning Tax Incentives for Ta xpayers Affected by the 2019 Corona Virus Disea se Pandemic. 
ISSN: $2247-6172$

Review of Applied Socio- Economic Research

(Volume 22, Issue 2 2021), pp. 21 -36

URL: http://www.reaser.eu

e-mail: editors@reaser.eu

[44] Z. Leong, TH. Lee, M. T. Teoh. (2020). Tax Compliance and Tax Incentive: an Investigation of SMEs during the Covid-19Period. International Journal of Academic Research in Accounting and Management Sciences, Vol. 10 , No. 3, P. 451-474.

[45] CentralBureau of Statistics. https://www.bps.go.id

[46] DirectorateGeneral of Taxation. https://www.pajak.go.id

[47] The Ministry of Cooperative and Small and Medium Enterprises, the Republic of Indonesia. https://kemenkopukm.go.id

Manuscript received: 09.09.2021

Manuscript received in revised form: 13.10.2021

Manuscript accepted: 15.10.2021 